\title{
Requirements for developing ethical leaderships in Vietnam
}

\author{
Nguyen Hai Thanh ${ }^{1 *}$, Nguyen Van Quang ${ }^{2}$ \\ ${ }^{1,2}$ Ho Chi Minh National Academy of Politics, Hanoi, Vietnam \\ *Corresponding author, e-mail: thanhhaitlh@gmail.com
}

\begin{abstract}
Challenges associated with leadership practices are rapidly increasing, thereby assigning more qualities to leaders. One of the recent theoretical issues that interest many scholars is ethical leadership development, using industrial revolution 4.0. This method does not only follow the traditional leadership styles, rather it is associated with universal qualities such as respect, service, fairness, honesty, and responsibility. For communities, increasing assertions is one of the essential foundations used to help leaders influence their subordinates' actions. This means that ethical leadership is the motto of the spirit of service leadership, especially for Vietnam leaders, a country with a strong transformation from a planned economy to a socialist-oriented market. Therefore, leadership values need to be adjusted, supplemented, and developed to keep up with the Industrial Revolution's requirements 4.0.
\end{abstract}

Keywords: Ethics, Leadership, Ethical leaderships, industrial revolution 4.0.

How to Cite: Thanh, N. H., \& Quang, N. V. (2020). Requirements for developing ethical leaderships in Vietnam. International Journal of Research in Counseling and Education, 4(2), 82-91. doi: https://doi.org/10.24036/00167za0002

This is an open access article distributed under the Creative Commons 4.0 Attribution License, which permits unrestricted use, distribution, and reproduction in any medium, provided the original work is properly cited. $@ 2020$ by Author.

\section{Introduction}

Historically, the idea of moral leadership has been in existence since the creation of the earth. Northouse (2007) stated that moral leadership is associated with Plato (427-347 B.C.) and Aristotle's (384-322 B. C.) conception in the West. Meanwhile, in the East, it is associated with the doctrine of virtue by Khong Tu (551479 BC), which was further supplemented and developed by Manh Tu (372-289 BC) and Tuan Tu (298-238 $\mathrm{BC})$. According to the concept of virtue, the military needs to meet the conditions of achieving virtue and attaining religion. Minh and Thuy (2015) stated that the honorable man's virtue is the brave monk that ruled the earth thousands of years ago. Until the late twentieth century, several studies have been conducted on moral leadership, such as business ethics (Beauchamp \& Bowie, 1988), biomedical ethics (Beauchamp \& Childress, 1994), and educational leadership (Komives, Lucas \& McMahon, 1998) with universal values, such as respect, service, fairness, honesty, and responsibility. The leader does not use administrative measures because workers voluntarily carry out instructions.

Kunhiyop (2008) reported that the theoretical studies of ethical leadership focused on the right and wrong arguments for a prolonged period, until recently, when ethical leadership studies become more popular and systematically developed. Furthermore, various studies have also been conducted on the ethical leadership structures from previous theoretical examination (Brown, Trevino, \& Harrison, 2005). However, these studies' contents had different approaches, although they recognized the importance of ethical leadership (Sendjaya, 2005).

Some studies were also carried out to demonstrate the components capable of creating effective leadership qualities in order to achieve positive results, using leadership and moral affirmations as two components with close ties (Dhar \& Mishra, 2001). Madanchian (2017) stated that leadership's effectiveness is associated with ethical leadership to create and maintain positive results based on common values recognized by people. High unity between ethical leadership is also found in their behavior, which is positively related to leadership's effectiveness (Hazlina, Azlan \& Abdul, 2012; Marshall, 2012). According to Ciulla (1995), ethical leaders are effective and reliable with good morals, however, they also possess some actions that are sophisticatedly hidden away from their subordinates. Ciulla further stated that leaders' incompetence in the short and long term can lead to unethical results (Ciulla, 2005). 
Studies on ethical leadership are continuously supplemented and developed (Brown, Trevino \& Harrison, 2005). However, moral values such as humanity, tolerance, service spirit, fairness, accountability are unchanged. Li (2013) stated that ethical leadership is becoming the focus of most modern leadership studies. This is because one of the important motivations for creating an honest society is through ethical leadership (Madanchian et al., 2017). In the context of technological revolution 4.0, it needs to be more concerned with research and practice. This research aims to clarify ethical leadership by reviewing relevant documents and providing definitions for building it in Vietnam. The research questions aim to determine the importance of moral leaders' personality traits in Vietnam, strategies used by ethnical leaders in motivating staff, and the requirements needed by leaders to meet with the industrial revolution 4.0. This research structure examines the purpose and analyzes the questions.

Several studies affirm that leaders do not lack the role of ethical leadership (Gini, 2004). Lao Tu (1972) reported that leadership is ranks given to honorable men in society, therefore, there is a need for them to possess adequate knowledge, with the ability to restore peace in terms of conflicts. Moral scandals by selfish and arrogant leaders cause stress on employees, and it is, therefore capable of shaking the foundations of many long-standing organizations (Bernard \& Ronald, 2019). Leadership without the role of morality creates instability for the organization, which can cause serious consequences for society. Poor leadership qualities create dissatisfaction and inhibit the successful growth of any society. Therefore, leaders need to be knowledgeable to provide solutions in extreme conditions (Conger \& Kanungo, 1998).

Similarly, unethical behaviors can become part of organizational culture, thereby making the spirit of solidarity among the organization's members lose (Caldwell, Karri \& Matula, 2005). Poff (2004) stated that leadership is associated with challenges, and high complex contexts, which are expected to be easily overcome by leaders (Poff, 2004). These assertions serve as an important role of ethical leadership on stability, building organizational culture, and establishing common values to achieve the stated leadership goals.

\section{Discussion}

\section{Ethical leadership}

Ethical leadership plays an important role in providing orientation and in organizing the mission and vision to achieve leadership goals, in the spirit of service, altruism, and leading responsibility in leadership strategies (Kanungo \& Mendonca, 1996). Ethical leadership is the expression of the individual leader's behavior in creating a relationship to inspire and promote leadership goals (Brown, Trevino \& Harrison, 2005). According to Ayoub (2014), ethical leadership means eliminating coercion through persuasive educational methods that motivate individuals to promote self-worth. Some studies consider it the right leadership method (Freeman \& Stewart, 2006), with the behavior common to every leader, as behavioral standards ethics (Thomas, 2001). Furthermore, popular moral values become the rules of general treatment applied to leadership, to enhance its effectiveness, which is different from bureaucratic and administrative orders.

Ethical leadership is essential in realizing the leader's mission and vision of an organization by striving to achieve success without using the position to achieve personal goals (Beauchamp \& Bowie, 1988). Hoogh and Hartog (2008) reported that ethical leadership comprises three components: fair values, power-sharing, and leaders' role. Yukl (2010) stated that it always shows a strong, clear, and consistent self-identity. Therefore, it is categorized as an abstract that is difficult to identify with various factors (Yukl, 2006). Specific manifestations of ethical leadership or its structure show that moral values are irreplaceable, emphasizing the strategies used to identify them differently.

Ethical leadership has many similarities with democratic leadership, with the ability to make others aware of the individual differences that need to be always respected (Kitchener, 1984). According to Rost (1991), it does not allow subordinates to act freely, rather it contains principles associated with the values, norms, and general rules of society. Therefore, leaders need to be clearly aware of each person's citizenship and ensure it is in line with their predetermined values (Burns, 1978). Ethical leadership principles need to become a pattern of behavior capable of motivating employees, which also acts as a sense of responsibility, tolerance, honesty, integrity, and fairness (Tracy, 2016). These factors increase the effectiveness of leaders in inspiring others.

Moral qualities are an integral part of ethical leadership, which is associated with the traditional ways determining subordinates' behaviors (Gilligan, 1982), promoting voluntariness, and recognizing individual differences (Bass \& Steidlmeier, 1999). They also uphold the essence of service (Block, 1993; Covey, 1990; De Pree, 1989; Gilligan, 1982; Greenleaf, 1977; Kouzes \& Posner, 1995). Today's traditional moral leadership 
does not diminish in value, and cannot be considered unnecessary, therefore, it is added and developed to suit the context and nature of modern leadership.

In addition, ethical leadership uses power and authority by position and law to determine the characteristics of values, norms, attitudes, beliefs, procedures, and behaviors consistent with institutions' requirements (Mihelic, Lipicnik \& Tekavcic, 2010). Therefore, it acknowledges the moral leadership remains, which is intimately associated with social institutions. Katarina et al (2010) listed some of the ethical and unethical leaders' behaviors, as shown in Table 1.

Table 1. Ethical and unethical leadership

\begin{tabular}{lc}
\hline \multicolumn{1}{c}{ The Ethical Leader } & The Unethical Leader \\
\hline Is humble & Is arrogant and self-serving \\
Is concerned for the greater good & Excessively promotes self-interest \\
Is honest and straightforward & Practices of deception \\
Fulfills commitments & Breaches agreements \\
Strives for fairness & Deals unfairly \\
Takes responsibility & Shifts blame to others \\
Shows respect for each individual & Diminishes others' dignity \\
Encourages and develops others & Neglects follower development \\
\hline
\end{tabular}

Table 1 shows that ethical leadership is the application of norms, values, and principles by leaders according to social institutions expressed through their behavior. Furthermore, it demonstrates the leader's role in directing and leading subordinates according to the common values that the organization needs to achieve. Ethical standards are applied to leadership and psychological mechanisms that are uniformly spread to motivate employees to work. Gini (2004) stated that leadership and morality are inseparable because leaders' behaviors are collectively expressed.

\section{Industrial revolution 4.0, challenges and opportunities}

The term industrial revolution 4.0 was put forward by Klaus Schwab, founder and executive chairman of the World Economic Forum, by focusing on the inventions, innovations, and combinations of the physical, virtual, and biological worlds. These are "great coins" characterized by technological integration, thereby eliminating the boundary between physics, digital, and biology, with a combination of virtual and practical systems (Schwab, 2015). Industry 4.0 comprises of 15 key areas (Thuong, 2017), namely 1) Big Data, 2) Smart Cities, 3) Blockchain/Bitcoin, 4) Artificial Intelligence, 5) Renewable Energy/Clean-tech, 6) FinTech, 7) ECommerce, 8) Robotics, 9) 3D Printing, 10) Virtual/Augmented Reality, 11) Shared Economies, 12) Internet of Things, 13) Nanotechnology/2D Materials, 14) Biotechnology/Genetics \& Agricultural Innovation, and 15) Desalination and Enhanced Waste Management.

The current revolution, which led to unprecedented breakthroughs, is disrupting almost every industry worldwide, and this heralds the transformation of the entire production and management system. Schwab (2015) stated that decision-makers are traditionally enthralled or engrossed in immediate concerns without considering new strategies and challenges that shape the future.

A significant percentage of the Industrial Revolution losses are related to the government's policy, which leads to greater inequality, thereby breaking the potential for labor market vulnerability (Min Xu et al., 2018). According to Wolf, low-skilled jobs are currently replaced by computers and digital tools, while those that require adequate skills are paid higher, less likely to be replaced, and potential to increase social tension (Wolf, 2015). Besides job-related risks, there are many other challenges, such as network security, hacking, risk assessment, and key security-related factors (Lambert, 2017). Romney \& Steinhart (2018) stated that threats and losses from ongoing cyber-attacks are larger and greater. Although Schwab and several other studies stated that there are enormous challenges associated with the impact of the industrial revolution 4.0, it was both frightening and interesting, as human lives are likely to change with the birth of artificial intelligence (AI), Internet of Things (IoT), Big Data, the creation of new generation robots, 3D printing technology and the integration of technologies. These tools are going to improve the quality of life for many people around the world, opening new markets, and promoting economic growth (Jee, 2017).

Xu, David \& Kim (2018) summarized and raised 5 opportunities from the industrial revolution 4.0, as follows 1) reducing barriers between inventors and the market due to new technologies, 2) the trend of artificial intelligence contributes to a reasonable resolution of complex issues that pose as a threat to employment, providing new directions for economic growth, 3) the integration of advanced technology contributes to the science and engineering sectors that blur the boundaries between the fields of physics, digital and biology, 4) robots are likely to change human lives in future and 5) Internet of things (IoT). 
The industrial revolution 4.0 tends to fundamentally change the way people live, work, and create opportunities. However, it also poses challenges in terms of transformation, which is considered thoroughly by governments in public and private sectors (Schwab, 2015).

\section{Theoretical Framework}

This framework is based on the Complexity Leadership Theory (CLT) and leadership theory of Tran Long Van (2016). CLT puts leadership in line with the context, goals, and modes. This approach is considered consistent with the development of moral standards and values in the digital context to make leadership decisions based on the leader and family's subjective will.

Several studies show that leadership effectiveness is not moral, therefore, the presence of morality is dependent on the competency of each leader's talent, and artistic skills (Northouse, 2004). Sendjaya (2005) stated that leadership and ethics are inseparable in examining the ethics of transformational leadership, which is very much dependent on moral values (Sendjaya, 2005). In societies with strong changes, social context is used to form new social institutions, the mass gathering based on the moral foundation is essential. In such scenes, the promotion of moral behavior in employees can be seen as a leadership challenge (Marrella, 2001), thereby leading to greater moral standards.

The theory of five elements proposed by Tran Long Van (2016) is based on the law of impact of five factors, namely leader, followers, leadership context, goals, and methods. Therefore, ethical leadership needs to be based on the close relationship of the five elements, which are set in the context of the industrial revolution 4.0, and expressed in the following model:

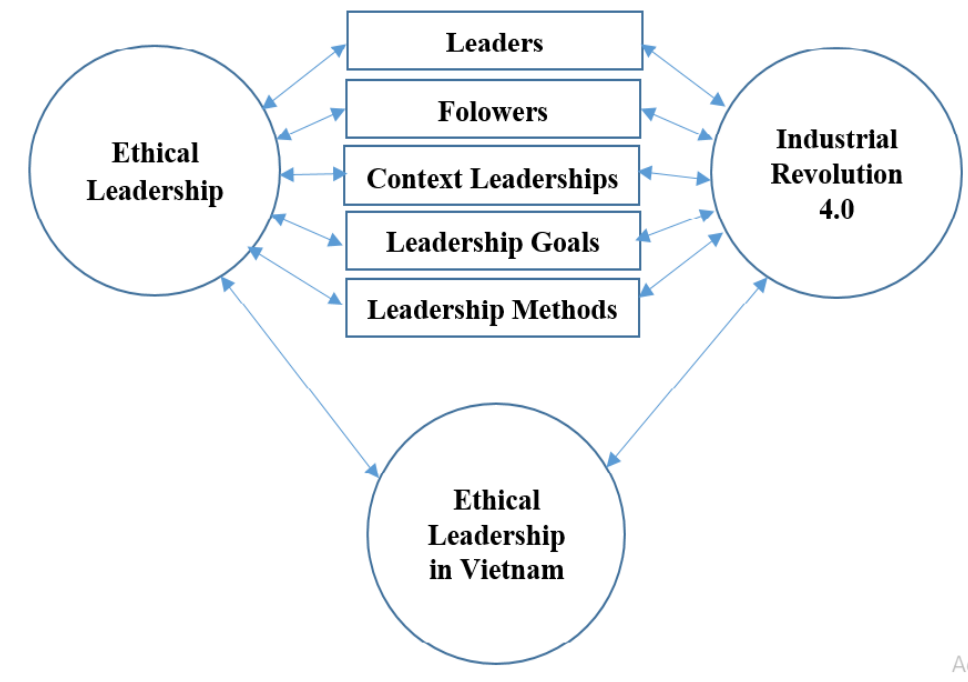

Figure 1. The Framework Based on Complexity Leadership Theory (CLT) and leadership theory of Tran Long $\operatorname{Van}(2016)$

\section{Ethical leadership in industrial revolution 4.0 and ethical leadership in Vietnam}

In industrial revolution 4.0, public and private sectors are currently going through an ethical crisis in leadership practice (Lyal, 2019). Organizations and governments promote workplace automation with new technologies such as artificial intelligence mortgage approval, machine-based assistant, algorithm manager, etc. Such technological advances pose a series of questions for organizations and societies, namely, what is leadership's purpose in the age of technology 4.0? Which model for public agencies has the best capability to serve the society in the coming decades? How can human dignity be protected in an algorithm-based society? Do robots need to be taught ethics? (Hooker \& Kim, 2019). In the technology revolution 4.0, the use of cloud computing, social networks, data analysis, IoT, artificial intelligence, blockchain, and other technological progress raises the following question on humanity: Does the development of artificial intelligence harm people, and is anyone responsible? According to Brynjolfsson \& McAfee (2014), robots have been taking over people's jobs at an unprecedented scale. Therefore, it is necessary to determine the ethical leadership of leaders for society's future, especially in the industrial revolution 4.0.

The ethical leadership in the industrial revolution 4.0 means creating a better society, where the leader always considers the subordinate as the object of service. Costa (1998) stated that subordinates' inherited 
moral values demonstrate the avoidance of responsibility, respect for human dignity, and humanity with unprecedented steps based on modern technology foundations. With the strong development of modern technology platforms, people can interact with public agencies, thereby contributing to enhancing transparency and accountability in managing leaders at all levels. According to Maktoum (2016), to build a strong government, the leadership concept needs to be changed to avoid social, economic, and political consequences. Therefore, when the leader ignores ethical issues, equality between the state and the people must be constitutional.

Qusthan Firdaus (2019) raised four leadership challenges in the industrial revolution of 4.0. Firstly, the perceived gap between developing countries' inabilities to catch up with high technology in developed countries. Secondly, the accessibility, quality, and quantity of information between people and public agencies, while the third is associated with the strategies used to reduce the negative effects of automation on human. Finally, the labor that needs to be adhered to by robots and artificial intelligence must adhere to ethical standards and be treated as impartial evaluation. The leader that fails to address these challenges is considered incapable of moral leadership, and unable to develop the new technological revolution.

Therefore, ethical leadership in the industrial revolution 4.0 promotes newly formed values such as building a government of integrity, constructivism, and action, serving people (Hung, 2017). In order to build trust, the leader needs to dismiss personal needs, with collective moral support, and this is likely to affect the future development of the organization (Van, 2016). Besides, the humble leader always adheres to organizational rules, using human power, exemplary actions, and noble moral qualities to influence others, thereby obtaining respect from subordinates.

The technological revolution allows the connection between leaders and subordinates, which creates an atmosphere for proper work relationships and assigned responsibility (Lanik, 2019). Mc Call and Hollenbeck (2002) stated that some of the qualities of global leaders in the 21st-century perseverance, optimism, honesty, and integrity. Leaders need to harmonize the relationship between growth and sustainable development, pay attention to all employees' lives, ensure equity, and create social responsibilities for the leading force. The frankness, sincerity, and commitments to the people are standards of morality and civilization. Therefore, these leadership qualities need to be considered an important requirement for leaders in the digital era.

Ethical leadership in the industrial revolution 4.0 requires leaders capable of understanding its nature and making strong commitments. For instance, Tracy (2017) stated that leaders need to be willing to take responsibility, never criticize or blame objectively, respect other people's opinions, and listen to subordinates to feel connected (Lanik, 2019). Ethical leadership is associated with the ability to gather, inspire, encourage employees to participate in leadership decisions, and build trust and action for a better society. Ethical leadership in the industrial revolution 4.0 is to inherit and apply creativity and flexibility of traditional standards while applying new moral values such as information sharing, responsibility, accountability, transparency, vision creation, service spirit, and respect for humanity.

Furthermore, it emphasizes the mechanism of controlling and balancing the power between leaders and people to enjoy leadership results from the economy's orientation. Leaders need a strong sense of development for the common interests and happiness of society.

\section{Ethical leadership in Vietnam}

Many cadres and party members, including leaders, do not lead by example, with a lack of cultivation and training. Furthermore, their ideological stand is unstable, confused, and fluctuated by external influences, thereby falling into self-centered, narrow-minded individualism, tempted by material interests, making them unable to fulfill their responsibilities and obligations to people (CCCPV, 2016). In the 1947 policy titled "Sua doi loi lam viec," President Ho Chi Minh addressed revolutionary moralitymorality's expressions, such as greed, laziness, arrogance, obedience, indiscipline, and narrow mindedness. The President also stated that the revolutionaries need to possess five attributes, namely humanity, meaning, mind, courage, and integrity (Ho Chi Minh, Vol. 5, 2002). Furthermore, in the 1969 article titled "Nang cao dao duc cach mang, quet sach chu nghia ca nhan" the President reported that the leader must put the interests of the people first, to foster collective ideology and spirituality, while ensuring solidarity, and discipline in the organization (Ho Chi Minh, Vol. 12, 2002). Before the industrial revolution 4.0, many new social manifestations emerged, therefore, the leader needs to possess a high level of morality, self-expression, self-transformation, and evolution to avoid falling into a state of degradation (CCCPV, 2016).

Besides the above manifestations, most cadres, civil servants, and officials are determined to meet the Party's goals and ideals and do their utmost to serve the Fatherland and the people (PVCP, 2011). On the 
other hand, the current leadership team has been identified with a strong ideological and political-ideological stance, with a simple and exemplary lifestyle and discipline. Many leaders are dynamic, creative, adapting to the integration trend, and working in the international environment (CCCPV, 2018). However, the Industrial Revolution 4.0 sets higher demands for each leader, they respond to traditional moral values and can dominate themself against negative impacts.

\section{Requirements on building and training ethical leadership for leaders in Vietnam in the industrial revolution 4.0.}

Vietnam is a developing country with many difficulties and challenges, required to transform the old society into a new one. According to Ho Chi Minh (2002), it is the leader's responsibility to build and train cadres with leadership and working capacity to prevent failure (Maxwell, 2016). Therefore, consistent ethical behavior results from a more thorough socialization process than any training program (Katarina et al., 2010).

Firstly, build and train the sense of revolutionary moral qualities of the leaders.The Communist Party of Vietnam has promulgated the Regulation on standards of titles and frameworks for the evaluation of leaders and managers at all levels. According to law No. 89-QD / TW, August 4, 2017, the political ideology needs to have a passionate patriotism by putting the interests of the Party and people willing to sacrifice for the Fatherland's independence and freedom. In terms of morality, lifestyle, and awareness of discipline, the leaders need to be honest, modest, and sincere, with a simple lifestyle. Furthermore, in terms of competency and creditworthiness, the leader needs to have the ability to lead and direct the subordinates by promoting the combined strength of trusted officials, party members, and the masses (CCCPV, 2017). Therefore, each leader must have a sense of persistence and courage (CCCPV, 2016).

Challenges of recession in political thought are associated with morality, lifestyle, manifestations of "selfevolutions," internal "self-transformation," corruption, waste, negativity in a rolling part leadership is still serious (CCCPV, 2016). Therefore, it is necessary to be objective when selecting officials. President Ho Chi Minh (2002) stated that the importance of educating and cultivating moral consciousness for leaders is to modify their way of working because the success of an organization's failure depends on them. Therefore, staff training is important, especially in terms of the moral sense of the leader, resisting material temptations, and the ability to educate others. In the industrial revolution, people have to achieve prosperous life, with better welfare, such as health insurance and other benefits (Qusthan, 2019).

Assessing the ethical leadership capacity of current leaders, communication skills, and working ability are some of the requirements of the industrial revolution 4.0. However, these factors are still limited, with a decrease in willpower and superficial work, making it difficult for adequate development (CCCPV, 2018). The building's requirement, ethical training leadership, capacity, and prestige of leaders at the same level is an essential requirement of the era. Each leader must be self-conscious, conscious of overcoming the limitations of the regime.

Secondly, promoting administrative reform by attaching importance to the selection, training, and retraining of leaders. Public administration reform in Vietnam is seen as a government strategy to build a clean, strong, modern, and effective system with state administrative agencies capable of increasing democracy. This can be achieved using 6 key tasks, including institutional reform, administrative procedure reform, reform of state administrative apparatus, public financial reform, administrative modernization, construction tasks, and improving cadres' quality. Furthermore, civil and public servants need to possess good moral qualities, political competence, high professional capacity, and dedication (GSRV, 2011). The training and retraining of leading cadres are also mentioned in the decision No. 225/QD-TTg approving plan for state administrative reform from 2016-2020 by the Prime Minister (2016). This is carried out based on the requirements of reviewing programs to train cadres and civil servants, in order to create a strong change by training and retraining cadres and civil servants to meet the qualifications and capacity of serving the people and the development of the country in accordance with the conditions of Vietnam and international integration requirements (TPMV, 2016).

Moreover, the Government of Vietnam is concerned and gives priority to strengthening the capacity to access the 4th industrial revolution by building a digital transformation strategy and prioritizing public development with the creation of digital technology, smart agriculture, tourism, and urban areas (TPMV, 2017). The absorption and effective application of the technology revolution enables the leader to change the conservative and bureaucratic way of thinking to produce a modern administration with improved, transparent, and quality online service for people and organizations (TPMV, 2016). A modern administration that contributes to healthy moral leadership, technology revolution 4.0 does not allow leaders to take power to replace capacity.

Furthermore, the proper understanding and application of leadership rules following the requirements of technology revolution 4.0 encourage growth and development (Nhan, 2018). This does not diminish the role 
of moral leadership, rather it reflects honestly and the moral qualities of the leader in enhancing the accountability and transparency of the modern administration.

\section{Conclusion}

In conclusion, ethical leadership is significantly contributing to the success of the leader through religious standards. Therefore, leadership and morality are indispensable for leadership effectiveness. Ethical leadership needs to be at the core of every nation's development strategy for them to achieve success. Poor leadership moral is the biggest barrier to realizing the fourth industrial revolution strategy. Ethical leadership is an inevitable part of effective leadership in the industrial revolution 4.0, with value-based leadership committed to carrying out the right job like accountability, transparency, integrity, constructivism, and promotes the application of technology by leaders as well as executives. Therefore, as a developing country, Vietnam needs to train leaders to build a strong, rich, democratic, and civilized society for people to have a prosperous and happy life.

\section{References}

Ayoub, A., A. (2014). Moral Leadership/Master Program in Religion in Peace and Conflict/Uppsala University/Sweden. Retrieved from https://www.researchgate.net/publication/272508777_Moral_Leadership.

Bass, B. M., \& Steidlmeier. (1999). Ethics, character, and authentic transformational leadership behavior. Leadership Quarterly, 10(2), 181-217.

Beauchamp, T. L., \& Bowie, N. F. (1988). Ethical theory and business ( $3^{\text {rd }}$ ed.). Englewood Cliffs, NJ: Prentice Hall.

Beauchamp, T. L., \& Childress, J. F. (1994). Principles of biomedical ethics ( $4^{\text {th }}$ ed.). New York: Oxford University Press.

Bernard M. Bass \& Ronald E. Riggio. (2019). Transformational Leadership. Nxb Tổng hợp Thành phố Hồ Chí Minh.

Block, P. (1993). Stewardship: Choosing service over self-interest. San Francisco: Berrett-Koehler.

Brian Tracy. (2016). Art of leadership, The Gioi Publishing House. Ha Noi, p.26-140.

Brown, M. E., Trevino, L. K., \& Harrison, D. A. (2005). Ethical leadership: A social learning perspective for construct development and testing.Organizational Behavior and Human Decision Processes, 97(2), 117-134.

Brynjolfsson, E., \& McAfee, A. (2014). The second machine age: Work, progress, and prosperity in a time of brilliant technologies. WW Norton \& Company.

Burns, J. M. (1978). Leadership. New York: Harper \& Row.

Caldwell, C., Karri, R., \& Matula, T. (2005). Practicing what we teach: Ethical considerations for business schools. Journal of Academic Ethics, 3(1), 1-25.

CCCPV. (2017). Prescribing the framework of standards, titles and framework of criteria for evaluation of leaders and managers at all levels. No. 89-QD / TW, August 4, 2017.

CCCPV. (2018). The Resolution of Resolution of the XIIth Seventh Conference on focusing on building a contingent of cadres at all levels, especially strategic, qualified, capable and prestigious, on a mission level. No. 26-NQ / TW, May 19, 2018.

Central Committee of the Communist Party of Vietnam. (CCCPV). (2016).Resolution of the XIIth Fourth Conference on strengthening Party building and adjustment; prevent and reverse the recession about political ideas,, moral, lifestyle and manifestations of "self-evolution", "self-transformation" internally. No. 04-NQ / TW, October 30, 2016.

Ciulla, J. B. (1995). Leadership ethics: Mapping the territory. Business Ethics Quarterly, 5(1),5-28.

Ciulla, J. B. (2005). Integrating leadership with ethics: is good leadership contrary to human nature? In P.J. Doh \& S. A. Stumpf (Eds.), Handbook on responsible leadership and governance in global business (pp. 159-179). Cheltenham UK: Edward Elgar PublishingLimited. 
Conger, J.A., \& Kanungo, R. N. (1998). Charismatic leadership: The elustive factor in organization effetiveness. San Francisco: Jossey-Bass.

Covey, S. R. (1990). Principle-centered leadership. New York: Fireside.

Dalla Costa, J. (1998). The ethical imperative: Why moral leadership is good business. Reading, MA: AddisonWesley.

De Hoogh, A.H.B., Den Hartog, D.N. (2008). Ethical and despotic leadership, relationships with leader's social responsibility, top management team effectiveness and subordinates' optimism: A multi-method study. The Leadership Quarterly. 19(3) 297-311.

De Pree, M. (1989). Leadership is an art. New York: Doubleday.

Dhar, U., Mishra, P. (2001), Leadership effectiveness: A study of constituent factors. Journal of Management Research, 1(4) 254-263.

Gilligan, C. (1982). In a different voice: Psychological theory and women's development. Cambridge, MA: Harvard University, Press.

Gini, A. (2004). Moral leadership and business ethics. In J. Ciulla (Ed.), The Heart of Leadership(pp.25-43). Westport, CT: Praeger Publishers.

Government of Socialist Republic of Vietnam (GSRV). (2011).Resolution promulgating the overall program of state administrative reform period 2011-2020. No. 30c / NQ-CP, November 8, 2011.

Greenleaf, R. K. (1977). Servant leadership: A journey into the nature of legitimate power and greatness. New York: Paulist.

Hazlina, A.N., Azlan, A., Abdul, H.H. (2012). Ethical and Socially Responsible Practices among SME OwnerManagers: Proposing a Multi-Ethnic Assessment. Journal of Southeast Asian Research.1-9.

Ho Chi Minh (2002).Complete, Vol.12, National Political Publishing House, Hanoi, p 494

Ho Chi Minh. (2002). Complete, Vol. 11. National Political Publishing House, Hanoi, p 601.

Ho Chi Minh. (2002). Complete, Vol.5. National Political Publishing House, Hanoi, p 244, 269.

Hooker, J \& Kim, T. W. (2019). Ethical Implications of the 4th Industrial Revolution for Business and Society. Business \& Society 360 (2019, Emerald)

Hùng, M. (2017). Developmental, integrity, active Government, serve people: Creating trust to "bloom" creativity, sublimation ideas. Retrieved from http://www.congdoan.vn/tin-tuc/thoi-su-487/chinh-phukien-tao-liem-chinh-hanh-dong-phuc-vu-nhan-dan-tao-niem-tin-de-“bung-no"-sang-tao-thang-hoay-tuong!-299956.tld.

Jee, Y.-S. (2017). Exercise rehabilitation in the fourth industrial revolution. Journal of Exercise Rehabilitation, 13(3), 255-256. Retrieved from https://doi.org/10.12965/jer.1735012.506

Kanungo, R. N., \& Mendonca, M. (1996). Ethical dimensions of leadership. Thousand Oaks, CA: Sage.

Katarina K. M., Lipičnik, B \& Tekavčič, M. (2010). Ethical Leadership. International Journal of Management \& Information Systems. Fourth Quarter 2010. Volume 14, Number 5. p 31-42.

Kitchener, K. S. (1984). Intuition, critical evaluation and ethical principles: The foundation for ethical decisions in counseling psychology.Counseling Psychologist, 12(3), 43-55.

Komives, S. R., Lucas, N., \& McMahon, T. R. (1998). Exploring leadership: For college students who want to make a difference. San Francisco: Jossey-Bass.

Kouzes, J. M., \& Posner, B. Z. (1995). The leadership challenge: How to keep getting extraordinary things done in organizations ( $2^{\text {nd }}$ ed.). San Francisco: Jossey-Bass.

Kunhiyop, S. W. (2008). African Christian ethics. Michigan, MI: Zondervan, Grand Rapids.

Lambert, L. (2017). The Four Challenges of the Fourth Industrial Revolution. Market Mogul. Retrieved from https://themarketmogul.com/industry-4-0-challenges/?hvid=2Gt2CE.

Lao Tu. (1972). Moral code. Book 2. Khai Tri bookstore,Sai Gon.

Li, C. (2013). Ethical Leadership in Firms: Antecedents and Consequences. The University of Alabama, p.108. 
Lyal White. (2019). Ethical leadership in industry 4.0. Retrieved from https://www.africanindy.com/business/ethical-leadership-in-industry-40-18840052, January 17, 2019.

Madanchian, M. et al. (2017). Leadership Effectiveness Measurement and Its Effect on Organization Outcomes. Procedia Engineering. 181, 1043-1048.

Madanchian, M., Hussein, N., Noordin, F., \& Taherdoost, H. (2017). The impact of ethical leadership on leadership effectiveness among SMEs in Malaysia, 11th International Conference Interdisciplinarity in Engineering, INTER-ENG 2017, 5-6 October, Tirgu-Mures, Romania, p.968-974.

Maktoum, M., R., A. (2016). Vision changes the country. The Gioi Publishing House. Ha Noi, p.244.

Marshall, A. (2012). Ethical Leadership, Prototypicality, Integrity, Trust, and Leader Effectiveness, in School of Global Leadership \& Entrepreneurship, Regent University, p.234.

Martin Lanik. (2019). Effective leadership skills, Publishing House of National Economics University, Hanoi, p.268.

Maxwell, J. C. (2016). Developing leadership skills. Lao DongPublishing House, Ha Noi, 72.

McCall, M.W., \& Hollenbeck, G.P. (2002). Developing global executives: The lessons of international experience. MA: Harvard Business School Press.

Minh, D.D., Thuy, N.V. (2015). Study the doctrine of virtue and the issue of building a Vietnamese socialist rule of law state. Journal of Social Sciences and Humanities. Episode 31, number 1 (2015) 52-58.

Nhan, H. (2018). Four-letter leadership, artistic leadership. Lao DongPublishing House, Ha Noi, $216,317$.

Northouse, P. G. (2007). Leadership ethics, leadership: theory and practice (pp. 341-370). Thousand Oaks: SAGE Publications.

Northouse, P.G. (2004). Leadership: Theory and practice, (3rd edition). Thousand Oaks, CA: Sage.

Poff, D. (2004). Challenges to integrity in University administration. Journal of Academic of Ethics, 2(3), 209219.

Politburo of Vietnamese Communist Party (PVCP). (2011). Directive No. 03-CT / TW on continuing to promote studying and following Ho Chi Minh's moral example, May 14, 2011.

Qusthan Firdaus. (2019). Four ethical challenges in industry 4.0. Retrieved from https://www.thejakartapost.com/academia/2019/01/08/four-ethical-challenges-in-industry-4-0.html

Renjen, P. (2019). The 4 types of leader who will thrive in the Fourth Industrial Revolution. Retrieved from https://www.weforum.org/agenda/2019/01/these-four-leadership-styles-are-key-to-success-in-thefourth-industrial-revolution/

Romney, M. B., \& Steinhart, P. J. (2018). Accounting Information Systems (14th ed.). New York: Pearson.

Rost, J. C. (1991). Leadership for the twenty-first century. New York: Praeger.

Schwab, K. (2015). The Fourth Industrial Revolution: What It Means and How to Respond. Retrieved from https://www.foreignaffairs.com/articles/2015-12-12/fourth-industrial-revolution

Sendjaya, S. (2005), morality and leadership: examining the ethics of transformational leadership. Journal of Academic Ethics, 3(75-86). DOI: 10.1007/s10805-005-0868-7.

Sendjaya, S. (2005). Morality and leadership: Examining the ethics of transformational leadership. Journal of Academic Ethics, 3(1), 75-86.

The Prime Minister of Vietnam (TPMV). (2016).Decision on approving the state administrative reform plan for the period 2016-2020.No. 225/QD-TTg, February 4, 2016.

Thomas, C. (2001). The Ethical Leader, Executive Excellence(Vol. 18, pp. 15): ExecutiveExcellence Publishing.

Thuong, N. N., (2017). Industry Revolution 4.0 and issues raised with Vietnam. Retrieved from http://csnd.vn/Home/Nghien-cuu-Trao-doi/3559/Cach-mang-Cong-nghiep-40-va-nhung-van-de-dat-ravoi-Viet-Nam, December 18, 2017.

TPMV. (2017).Decision on strengthening capacity to access the 4th industrial revolution.No. 16 / CT-TTg, May $4,2017$.

Van, T. L. (2016). Leadership Art. National Political Publishing House, Hanoi, p.104, 257, 270. 
Xu, M., David, J. M \& Kim, S. H. (2018). The Fourth Industrial Revolution: Opportunities and Challenges. International Journal of Financial Research. Vol. 9, No. 2; 2018, p 90-95.

Yukl, G. (2006). Leadership in organizations, 6th edition. New Jersey: Pearson Prentice Hall UpperSaddle River,NJ.

Yukl, G. (2010). Leading organizations. Prentice Hall. 